\title{
The Joggins Fossil Cliffs UNESCO World Heritage site: a review of recent research
}

\author{
Melissa Grey ${ }^{1,2 *}$ and Zoe V. Finkel ${ }^{2}$ \\ 1. Joggins Fossil Institute, 100 Main St. Joggins, Nova Scotia B0L 1A0, Canada \\ 2. Environmental Science Program, Mount Allison University, Sackville, New Brunswick E4L 1G7, Canada \\ *Corresponding author: <curator@jogginsfossilcliffs.net>
}

Date received: 28 July 2010 S Date accepted 25 May 2011

\begin{abstract}
The Joggins Fossil Cliffs UNESCO World Heritage Site is a Carboniferous coastal section along the shores of the Cumberland Basin, an extension of Chignecto Bay, itself an arm of the Bay of Fundy, with excellent preservation of biota preserved in their environmental context. The Cliffs provide insight into the Late Carboniferous (Pennsylvanian) world, the most important interval in Earth's past for the formation of coal. The site has had a long history of scientific research and, while there have been well over 100 publications in over 150 years of research at the Cliffs, discoveries continue and critical questions remain. Recent research (post-1950) falls under one of three categories: general geology; paleobiology; paleoecology. It provides a context for future work at the site. While recent research has made large strides in our understanding of the Late Carboniferous, many questions remain to be studied and resolved, and interest in addressing these issues is clearly not waning. Within the World Heritage Site, we suggest that the uppermost formations (Springhill Mines and Ragged Reef), paleosols, floral and trace fossil taxonomy, and microevolutionary patterns are among the most promising areas for future study.
\end{abstract}

\section{RÉSUMÉ}

Le site du patrimoine mondial de l'UNESCO des falaises fossilifères de Joggins est situé sur une partie du littoral qui date du Carbonifère, sur les rives du bassin de Cumberland, qui est une prolongation de la baie de Chignecto, elle-même un bras de la baie de Fundy. L'endroit offre un excellent milieu de préservation de la faune et de la flore dans leur environnement. Les falaises donnent un aperçu du monde du Carbonifère tardif (Pennsylvanien), soit la période de l'histoire de la terre la plus importante pour la formation du charbon. Ces falaises ont fait depuis longtemps l'objet de travaux de recherche scientifique et plus de 100 publications y ont été consacrées au cours de 150 années de recherche. L'endroit suscite encore des découvertes et il soulève toujours des questions essentielles. Les travaux de recherche récents (depuis les années 1950) se répartissent en trois catégories: géologie générale; paléobiologie; et reconstitution des paléomilieux, en plus d'offrir des avenues pour les futurs travaux qui devraient s'y dérouler. Même si la recherche récente a largement contribué à une meilleure compréhension du Carbonifère tardif, de nombreuses questions demeurent sans réponse et commandent qu'on les étudie et les résolve et il est manifeste que l'intérêt pour ces questions est bien loin de s'amenuiser. Sur ce site du patrimoine mondial, nous soutenons que les futurs sujets d'étude les plus prometteurs seraient les formations supérieures (Springhill Mines et Ragged Reef), les paléosols, la taxonomie florale et des ichnofossiles, ainsi que les paramètres de microévolution.

[Traduit par la redaction]

\section{INTRODUCTION}

The Joggins Fossil Cliffs site (Nova Scotia, Canada; Fig. 1), representing the interval from about 310 to $315 \mathrm{Ma}$, was inscribed on the UNESCO World Heritage List in 2008 for its outstanding representation of Carboniferous (Pennsylvanian) biota within their environmental context. Research and discovery at the site began over 150 years ago and continues today; and with World Heritage inscription, Joggins now has an even greater presence on the global stage. Since the mid-1800s, well over one hundred scientific papers have featured Joggins, and many more mention it. Excellent accounts of the early research at Joggins, from the mid-1800s to the mid-1900s, have been undertaken by Calder (2006), Falcon-Lang (2006), Rygel and Shipley (2005), and Scott (1998). However, no in-depth review exists of recent work, from about 1950, encompassing the entire World Heritage Site, a gap that we fill with this contribution.

Much of the research at Joggins can be placed into one of three categories: geology (e.g., sedimentology and petrology); paleobiology (including discovery and taxonomy); and pa- 


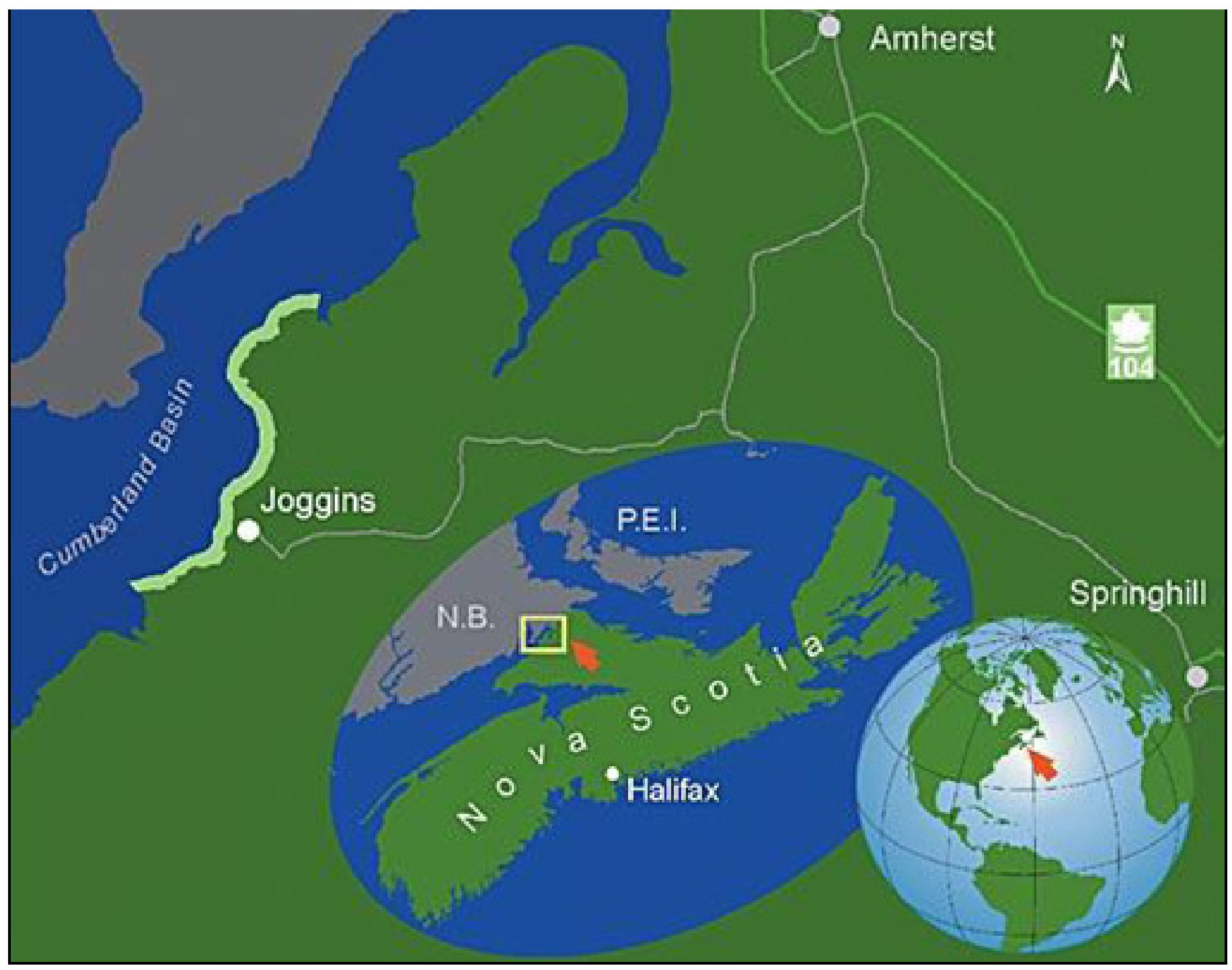

Fig. 1. Location (in light green) of the 14.7-km -long Joggins Fossil Cliffs UNESCO World Heritage Site section along the shore of Cumberland Basin, Nova Scotia, Canada (modified from Boon and Calder 2007).

leoenvironmental reconstruction, which builds on the first two categories. We review the research within each of these categories as it relates to the World Heritage Site section and outline what we see as critical future work.

\section{GEOLOGIC SETTING}

\section{Stratigraphy, Sedimentology and Sedimentary Environments}

Some of the largest strides in research at Joggins have been in sedimentology and stratigraphy, providing a context and framework for all other recent work. The Joggins Fossil Cliffs site comprises a 14.7-km-long coastal section. The pioneering Canadian geologist, William Logan, first described the section at Joggins in 1843 and logged over $4 \mathrm{~km}$ of it in just five days (Rygel and Shipley 2005). Over the next 150 years, the sedimentology and stratigraphy of the section were revised by several researchers, including Dawson (1868), Bell (1912, 1914, 1944) and Copeland (1959). To date, the most complete lithostratigraphic investigations of the entire Joggins section remain those by Ryan et al. (1991) and Ryan and Boehner(1994). Ryan et al. (1991) were the first to delineate and name formations and informal members in the Cumberland Group, and this work was expanded upon by Davies et al. (2005), Calder et al. (2005a) and others. Recent tectonostratigraphic work on the oldest, Mabou Group, part of the section was the subject of a M.Sc. thesis by McLeod (2010). Today, the section is considered to include units of the Early Carboniferous (Mississippian) Mabou Group (Shepody and Claremont formations) and the Late Carboniferous (Pennsylvanian) Cumberland Group (Boss Point, Little River, Joggins, Springhill Mines, and Ragged Reef formations) (Fig. 2). 


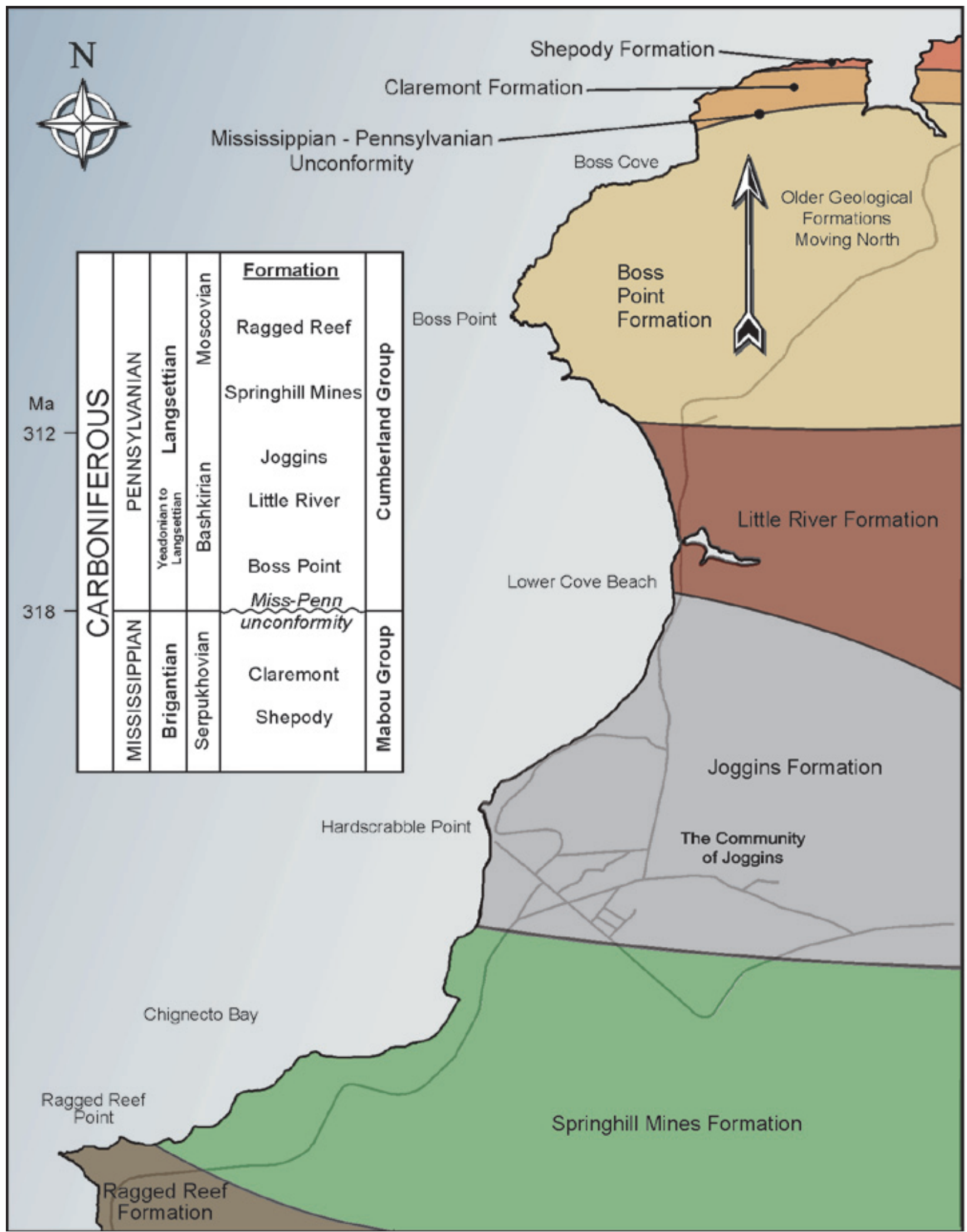

Fig. 2. Geological map of the Joggins Fossil Cliffs and their hinterland, showing the distribution of the formations. The stratigraphic column in the inset depicts the formations and their ages (modified from Boon and Calder 2007). The along-shore distance from Shepody Formation to Ragged Reef Point is $14.7 \mathrm{~km}$. 


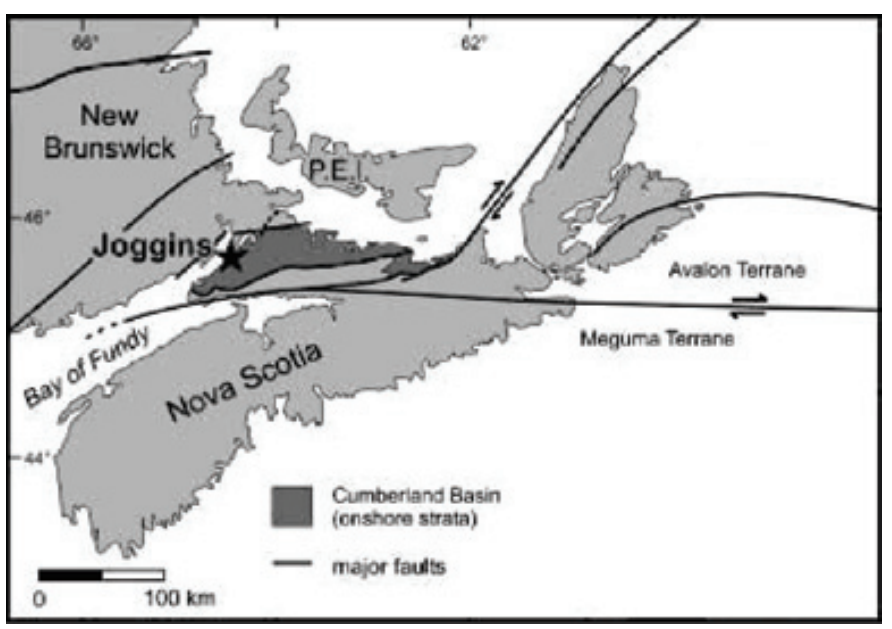

Fig. 3. Setting of the Cumberland Basin in relation to major faults within parts of the regional Maritimes Basin (modified after Rygel et al. 2004).

Only sedimentary rocks are found within the section, making radiometric dating impossible; however, based on palynological data from parts of the section (e.g., Dolby 1991, 2003; Utting et al. 2010) and the latest widely accepted geological timescale for the Carboniferous (Davydov et al. 2004; Davydov et al. 2010), the section most likely represents an interval of nearly 15 million years. Utting et al.'s (2010) detailed work is the first published study of the palynofora from the Joggins area and includes the entire World Heritage Site; their results indicate that the section ranges in age from the Brigantian (late Visean) to the Langsettian (Bashkirian?). However, Utting et al. note that palynological correlations are approximate as assemblages in the younger part of the section are of low diversity and many diagnostic taxa are absent.

The sedimentary exposure at Joggins is situated in the Cumberland depocentre, which forms part of the regional Maritimes Basin complex of Atlantic Canada (Gibling 1995; Gibling et al. 2008)(Fig. 3). The strata at Joggins are tilted as part of the Athol Syncline (see Reed et al. 1993). In a seismic study of the Athol Syncline, Waldron and Rygel (2005) showed that the rapid subsidence evident in the Cumberland Basin was caused by withdrawal at depth of Mississippian evaporites, allowing for the build up and preservation of a thick sequence of sediments and the fauna and flora found within them.

Sedimentological studies show that at sea-level highstand, this basin would have been connected, albeit distantly (based on the absence of common marine horizons), to the openocean as indicated by brackish incursions (Duff and Walton 1973; Archer et al. 1995; Skilliter 2001; Falcon-Lang 2005a) and drainage patterns (Gibling et al. 1992). At lowstand, the basin became restricted and was probably intracontinental (FalconLang 2006). Based on paleoflow patterns in the Boss Point, Little River, Joggins, and Springhill Mines formations, paleoflow was derived variously from the Cobequid and Caledonia highlands (Rust et al. 1984; Browne and Plint 1994; Calder 1994; Calder et al. 2005a; Rygel and Gibling 2006).

Sedimentological studies have also revealed the changing pa- leoclimatic conditions reflected in the World Heritage Site succession. Conglomeratic red beds of the Mabou Group indicate that arid conditions were widespread during the Mississippian in the Cumberland Basin (Hamblin 2001; Waldron and Rygel 2005). However, Pennsylvanian sediments mark a significant paleoclimatic change (Calder 1994). That humid conditions were common in the Pennsylvanian is reflected first in the Boss Point Formation (the basalmost Pennsylvanian formation) in part by the presence of coals (Gibling and Rygel 2008) and thick sandstone deposits from large river systems, demonstrating alternate braidplain and shallow lacustrine deposits (Browne and Plint 1994; Plint and Browne 1994). The top of the Boss Point Formation has calcareous paleosols and red floodplain deposits marking the beginning of semi-arid conditions that continue into the overlying Little River Formation (Gardiner and Gibling 2005; Gibling and Rygel 2008). Seasonal drylands were prevalent during the deposition of the Little River Formation, reflected by the lack the coal and limestone beds. In contrast, coal and limestone beds are extensive within the younger Joggins Formation and reflect the wetland conditions (Calder et al. 2005a). As the basin floor subsided, the lithostratigraphic succession within the Joggins Formation indicates that conditions became progressively wetter, promoting widespread growth of lycopsid trees and seed ferns that, over time, became the raw material for coal formation. While conditions were generally humid, mature paleosols and varying abundance and thickness of coal beds and red beds indicate a seasonal paleoclimate during this time (Davies and Gibling 2003).

The lower part of the Springhill Mines Formation records alternations between poorly drained (wetland) and well-drained (dryland) facies, similar to those of the underlying Joggins Formation (Salg and Rygel 2008). The paleosols in the Springhill Mines Formation were probably formed under warm and humid conditions alternating seasonally with dry conditions (Smith 1991). At the top of the section is the Ragged Reef Formation, which has been considered in less detail than the other formations (though see Way 1968 and Rust et al. 1984). However, a study by Deal (1991) indicates that paleoclimate during deposition of the Ragged Reef Formation was warm and relatively dry when compared to the generally humid paleoclimate reflected by the older Pennsylvanian formations. Rust et al. (1984) found a lack of thick coal seams in the Ragged Reef Formation, whereas red colouration and channel sandstones became more abundant up-section within the formation. These observations were attributed to a low coeval water table and locally rapid subsidence.

Of particular focus in the literature has been the Joggins Formation, or "Classic Section", where nearly all of the important paleontological discoveries have been made. The Joggins Formation was deposited within an interval of less than one million years, probably during the Langsettian (Dolby 1991, 2003; Utting and Wagner 2005; Davydov et al. 2010). Davies and Gibling (2003) were first to detail the sedimentology and sequence stratigraphy of the Joggins Formation, including facies cyclicity. Davies et al. (2005) and Gibling and Rygel (2008) suggested that glacioeustasy may have been important in creat- 
ing the cycles. This research was followed by numerous other sedimentological studies, discussed below, that provided a basis for the paleoenvironmental interpretation of the Joggins site, including work on facies associations, fluvial deposits, and vegetation-induced sedimentary structures (VISS).

Three primary facies associations have been identified within the Joggins Formation: an open-water brackish association; and two terrestrial associations, a poorly drained coastalplain association and a well-drained alluvial-plain association (Davies and Gibling 2003). In a detailed analysis, Davies et al. (2005) described the Joggins Formation in terms of fourteen repeating cycles (or rhythms). Cycles within the 915.5-m-thick formation tend to begin with beds of coal and fossiliferous limestone, marking episodes of sea-level rise. Overlying these lithologies are sandstones and mudstones, which dominate the section and represent coastal-plain and alluvial deposits.

Fluvial deposits, including channel bodies, are common sedimentological features in the section, especially within the Joggins Formation. A recent study has also reported such structures in the Boss Point and Little River formations (Allen et al. 2011). Rygel and Gibling (2006) explored the numerous Joggins Formation channel bodies and their development in terms of intrinsic and extrinsic controls. The authors found that all the channel bodies could be defined as fixed, meandering or multistory, and that all types were represented in both coastal wetland and inland floodplain facies associations. Due to high subsidence rates (Waldron and Rygel 2005; Gibling and Rygel 2008) extrinsic factors, such as climate, eustasy and tectonics probably had a relatively small effect on the architecture and form of the channel bodies (Rygel and Gibling 2006).

Vegetation today has a considerable influence on the features of a landscape and, given the abundance of vegetation in the Pennsylvanian, it likely affected sediment accumulation and structures during that time also. Despite the extensive work on modern vegetation-induced sedimentary structures (VISS), one of the few studies of "fossil" VISS comes from Rygel et al. (2004). They identified seven types of VISS within the Joggins Formation: five are "simple" hydrodynamic structures that develop around a single plant or between several plants; and two types are "complex", developing from a decaying plant through infilling or soft-sediment deformation. The VISS structures are facies-limited: hydrodynamic types are present in both dryland and wetland settings, while decay-related types only occur in the dryland settings.

\section{Petrology}

Joggins is in an area that was settled because of its natural resources. Early First Nations people came to fish (the name Joggins is probably derived from the Mi'kmaq word Chegoggin, loosely translated as a "place of fish weirs"; Falcon-Lang 2009); and later, Europeans settled there to mine coal (Falcon-Lang 2009; Quann et al. 2010). Scientists studying coal formation in the 1800s noted that observations at Joggins helped them resolve the mystery of how coal formed (Scott 1998). Over a century later, scientists began to quantitatively study the same coal beds in order to understand their deposition, chemical and floral/faunal composition, and hydrocarbon potential.

The coal beds at Joggins have been described as having been deposited on small floodplains (Kaplan et al. 1985). The coals at Joggins and those of the Maritimes Basin in general contain high levels of vitrinite and sulphur (Gibling et al. 1989; Kaplan et al. 1985; Hower et al. 2000; Skilliter 2001) and higher-thannormal heavy-metal trace-element concentrations (Kaplan et al. 1985). Kaplan et al. hypothesized that these trace elements were derived from the exposed Cobequid Massif to the south. Coal beds within the section also vary in their content of lycopsid spores versus tree-fern spores, with tree-fern spores becoming relatively more abundant over time (Hower et al. 2000). Vegetation closely reflects climatic conditions; as the paleoclimate became less humid toward the end of the Pennsylvanian, lycopsid trees became less dominant and the tree ferns, as a group more tolerant to dryer conditions, increased in abundance (DiMichele et al. 2009 and references therein).

Gibling and Kalkreuth (1991) undertook petrographic analyses of Late Carboniferous carbonaceous limestones of Atlantic Canada, including material from Joggins, to determine hydrocarbon recovery potentials. While these authors found good to very good potentials for the rocks at Joggins, the beds are too thin to be economically viable (Gibling and Kalkreuth 1991). As with other studies (e.g., Archer et al. 1995; Davies et al. 2005), the authors found abundant bivalves, ostracods and vertebrate fragments within the limestones at Joggins and, based on the fauna, concluded that the units were laid down in shallow lakes or interdistributary bays with a possible marine influence (Gibling and Kalkreuth 1991). Skilliter (2001) studied coal petrology and coal geochemistry, in the process suggesting a distal marine influence for the Forty Brine section within the Joggins Formation. However, the extent of marine influence in the Joggins section has remained the subject of debate (e.g., Brand 1994; Archer et al. 1995; Skilliter 2001; Tibert and Dewey 2006) and will be further discussed below.

\section{Future Research}

While there have been many important advances in our understanding of the stratigraphy, sedimentology and petrology of the Joggins area, some critical gaps remain. For example, more information is required on the stratigraphy, depositional environment, and climate of the uppermost formations within the World Heritage Site, including the Springhill Mines and Ragged Reef Formations. There have also been numerous references to paleosols throughout the site, but a comprehensive study is lacking. Given the importance of these "fossil" soils to the growth of the plant life that is so exquisitely preserved at Joggins, this remains a significant gap.

\section{PALEOBIOLOGY}

To date, over 200 species have been recovered from the Joggins section (Joggins Fossil Institute, unpublished data), 
broadly encompassing the entire food web in the terrestrial realm (Fig. 4). The assemblage represents four animal phyla, five classes of vascular plants, and three genera of protozoans (foraminifera) (tables 2.1-2.4 in Boon and Calder, 2007). Fossils from Joggins include the world's earliest-known reptile (Hylonomus lyelli; Fig. 4), the world's earliest-known land snail (Dendropupa vetusta; Fig. 4), and the tracks of the largestknown land invertebrate (Arthropleura). The famous "fossil forests", including upright lycopsid and cordaite trees, occur throughout much of the Joggins section. These trees are of particular interest because they are preserved in situ and commonly contain remains of other organisms, collectively known as the tree-hollow fauna (see below).

Early papers from the 1800 s primarily describe new discoveries at the Joggins Fossil Cliffs. William Dawson, in particular, whose work has been summarized by Falcon-Lang and Calder (2005), Calder (2006) and Falcon-Lang (2006), extensively collected and studied fossils from Joggins. Many of the more recent discoveries and taxonomic studies are of the vertebrates, mainly amphibians, including the extinct groups of the microsaurs and labyrinthodonts; (e.g., Carroll 1963, 1966, 1967; Stevenson and Stevenson 1966; Stevenson 1967; Baird 1982; Godfrey et al. 1987, 1991; Milner 1996; Reisz and Modesto 1996; Holmes et al. 1998; Robinson et. al 2005; Holmes and Carroll 2010). Fewer papers have focussed on vertebrate and invertebrate trackways, but include those by: Ferguson $(1966,1975)$ on Arthropleura trackways (Diplichnites); Sarjeant and Mossman (1978), who reviewed vertebrate trackways; and Mossman and Grantham (1996) on an amphibian trackway (Dromillopus). Dawson (1890) and Matthew (1903, 1905) outlined 13 "species" of tetrapod trackways, but there has been very little recent work synthesizing the knowledge of vertebrate and especially invertebrate traces. It should be noted that Lucas et al. (2005) and Stimson and MacRae (2010) produced reviews of tetrapod and Diplichnites and Kouphichnium trackways, respectively, but these remain in abstract form. Dafoe et al. (2011) have also reported on the invertebrate traces at Joggins.

Very few studies have considered microfossils from Joggins, with the exception of palynological studies. Aside from broadening the evidence for prevailing flora, spores and pollen have provided a principal criterion for dating the Joggins Formation (e.g., Dolby 1991, 2003; Utting et al. 2005; Utting et al. 2010). Other micropaleontological work has involved foraminifera and ostracods; for example, Tibert and Dewey (2006) focused on the taxonomy of the Joggins microfossils, specifically the ostracods, which are especially abundant within the limestones. They assigned most of the ostracods they found in the Joggins Formation to a new genus, Velatomorpha, which they considered to have lived in brackish, estuarine-type paleoenvironments. This conclusion was based on faunal associations of Velatomorpha with other taxa, including ostracods they attributed to Carbonita spp. Carbonita occurs in a range of non-marine to brackish conditions, supporting the conclusion of Archer et al. (1995) that deposition of at least some of the aquatic beds took place in brackish water.

There has also been relatively little work on the taxonomy of Joggins plant material. Falcon-Lang (2005b) described adpressed tree-fern trunks and Mosle et al. (2002) described seedplant cuticles, but broader studies have yet to be published. A global review of the Coal Age macroflora has been undertaken by R. Wagner (Palaeobotanical Museum(IMGEMA-Jardín Botánico de Córdoba, Spain) and remains unpublished.

\section{Future Research}

The rates of publication and taxonomic discovery at Joggins have been explored by Falcon-Lang (2006), whose analysis indicates that the saturation point of discovery has not yet been reached. The potential for finding new species is still relatively high, making Joggins an exciting place for paleontologists. With an increased global awareness of the Joggins site since its inscription on the World Heritage List in 2008 and the presence of the Joggins Fossil Institute (which houses an interpretive gallery, fossil collection, and hosts guided tours of the site), discovery of new specimens has already increased from FalconLang's (2006) count of about 148 species to about 200 species. Some of this increase can be accounted for through recent taxonomic revision of previously described taxa, but this number also represents a true increase of new material.

Taxonomy remains the basis of almost all paleontological research. Future taxonomic research will be especially critical in several areas. Many reviews and revisions for the tetrapod fauna exist (e.g., Carroll 1964, 1969, 1970a, 1970b, 1982, 1992, 2001; Milner 1987), but as noted, relatively little work has been published on the floral and trace-fossil taxonomy, and thus these two areas represent significant current gaps.

From the authors' perspective, the next major steps for research at the site should be in the field of evolution, of which taxonomic work and morphological analysis of traits comprise the foundation. Hylonomus lyelli represents an important evolutionary innovation in the history of vertebrates, reflecting their full transition from water onto land; these first amniotic tetrapods have been the subject of numerous papers (e.g., Carroll 1992; Milner 1996; Reisz 1997; Benton and Donoghue 2007). One recent study has linked tetrapod diversification during the Late Carboniferous to rainforest collapse in the former Euramerican part of Pangea (Sahney et al. 2010); microevolutionary studies of the various taxonomic groups within the well-preserved Joggins assemblages, representing an approximately 15 -million-year interval, could add new insights into such research. In order to build capacity for these kinds of studies, a critical focus must be on collecting and repatriating stratigraphically constrained and well-preserved fossils. (Note that, as of 1982, all fossils found in Nova Scotia legally belong to the province and a Heritage Research Permit must be obtained in order to collect specimens. For permit information see www. museum.gov.ns.ca/fossil/protect/permits/html. After study, these specimens must be returned to the province and will be added to the collection of the Nova Scotia Museum. The Joggins Fossil Centre houses a collection of Joggins fossil material that is on renewable loan from the Nova Scotia Museum and is currently the primary repository for all new Joggins material). 

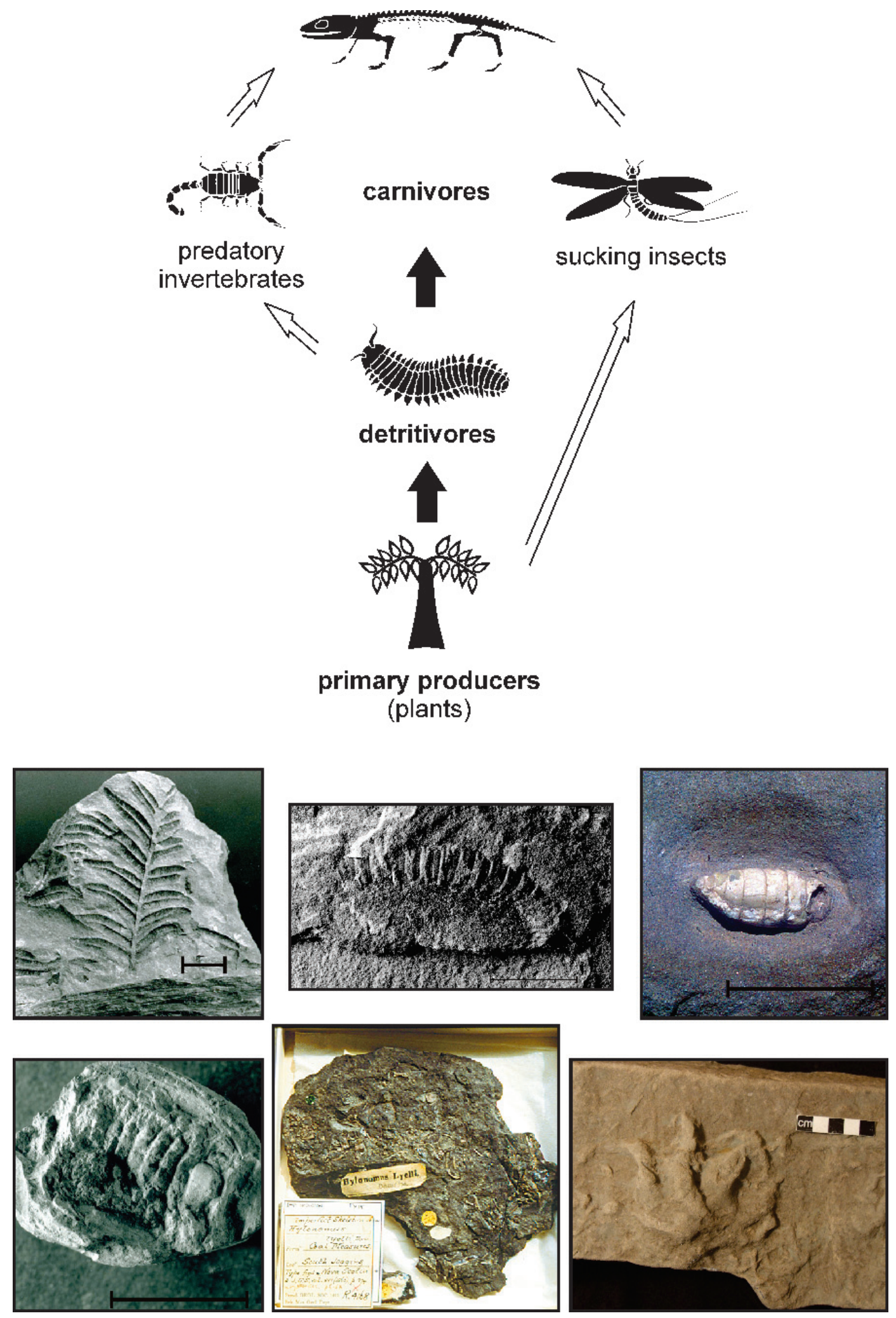

Fig. 4. The food web and representative fossils from different trophic levels in the terrestrial realm as represented at the Joggins Fossil Cliffs. Top left to right: Alethopteris (seed fern); Xyloiulus (millipede); Dendropupa (land snail). Bottom left to right: Graeophonus (whip spider, abdomen); Hylonomus (reptile); Pseudobradypus (taxonomy unconfirmed; amphibian and hypothesized as the top predator) trace fossil. Unless otherwise noted the scale bar in photographs is $1 \mathrm{~cm}$. Images courtesy Joggins Fossil Institute, M. Stimson, and J. Calder. 


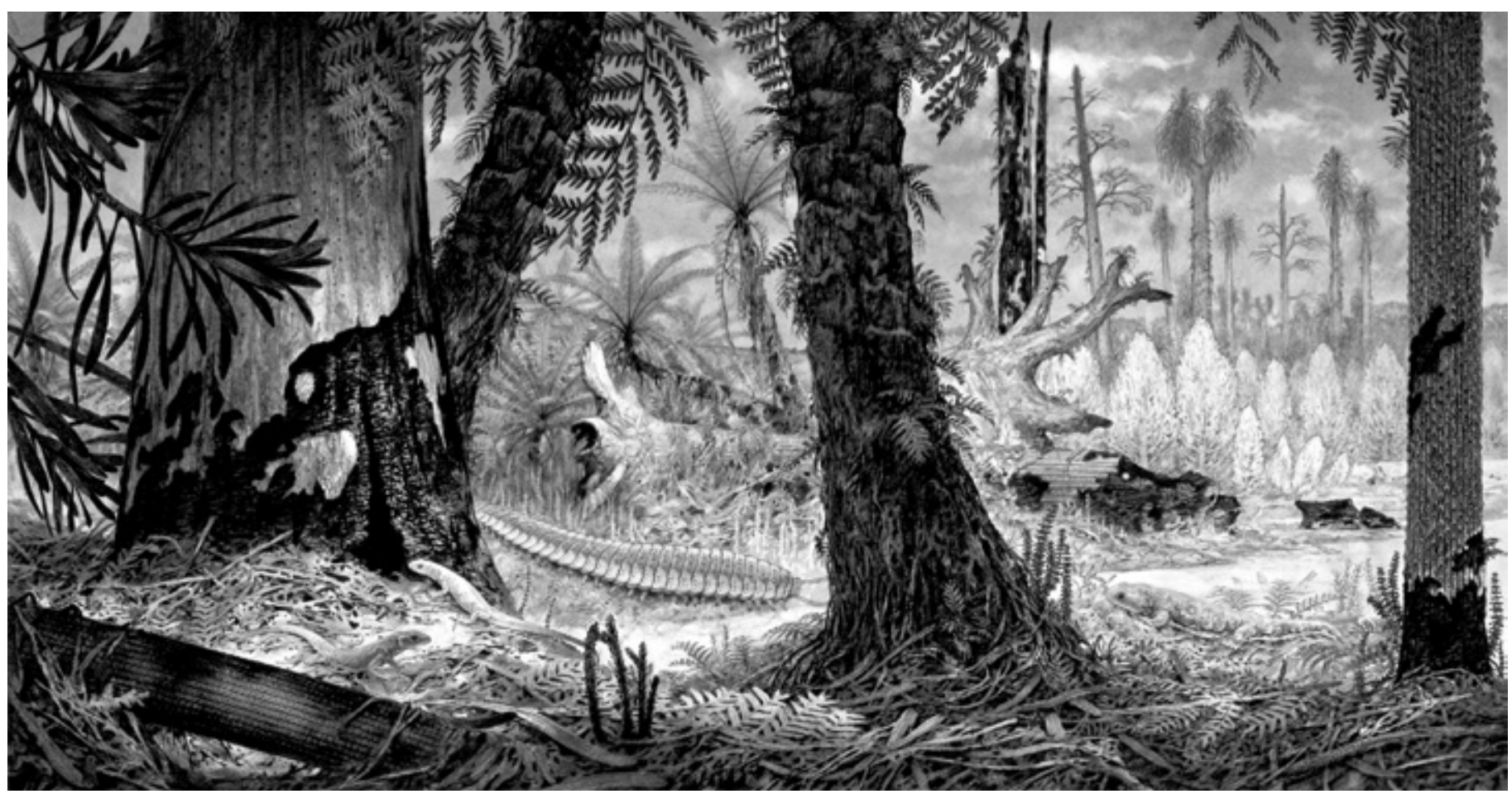

Fig. 5. Carboniferous forest scene as depicted by artist Doug Henderson. Reproduced with permission from the artist.

Linkages between oxygen and body size have been tested in numerous studies, most notably by Chapelle and Peck (1999) and Spicer and Gaston (1999), suggesting that gigantism (at least in amphipod crustaceans) is correlated with the concentration and partial pressure of oxygen. However, debate continues as to whether oxygen is a covariant and whether other environmental factors such as temperature are involved (Spicer and Gaston 1999). In insects, maximum body size is controlled by tracheal diffusion; therefore an increase in oxygen partial pressure would increase metabolism and allow for a larger body size (Graham et al. 1995). This factor most likely explains gigantism among insects in the Carboniferous and the ensuing extinction of such forms in the Permian when the partial pressure of oxygen fell to approximately two-thirds the value today (Spicer and Gaston 1999). We see the invertebrate fauna at Joggins as a potential testing ground for tracking linkages between atmospheric oxygen concentration, gigantism, and perhaps even diversity.

\section{PALEOECOLOGY}

An important factor contributing to the designation of the Joggins Fossil Cliffs as a World Heritage Site was that fossils found there are preserved in situ that is, in their paleoenvironmental context. Both sedimentological and faunal analyses serve as a foundation to reconstructing paleoenvironments. In general, the Late Carboniferous world evokes images of humid, rainforest-type settings (Fig. 5); this representation, however, is based on "classic" Carboniferous localities in eastern North America and western Europe that were situated in the paleo- tropics. We now know that the climate during this time period was more complicated, with some areas globally subhumid to perhaps even semi-arid (DiMichele et al. 2010). Geophysical data suggest that Joggins was near the paleoequator during the Carboniferous (DiVenere and Opdyke 1991) and therefore falls into the "ever-wet tropical" climatic belt (DiMichele et al. 2010) or "tropical peat forest biome" (Fig. 6).

As outlined above, sedimentological studies have revealed climatic changes throughout the World Heritage Site. In particular, the well-studied Joggins Formation shows cyclicity of facies associations and thus of paleoenvironments. Falcon-Lang (1999) and Falcon-Lang et al. (2004, 2006) related the sediments and their contained sedimentary structures and fossil assemblages to specific paleoenvironments. The Joggins Formation biota exhibits a cyclic succession that was probably climatically driven by glacial-interglacial cycles (Falcon-Lang 2003a). The succession has three primary components: a cordaite dryland community, a lycopsid wetland rainforest community, and an aquatic paleoenvironment representing perhaps proximal influence of maximum transgressions (Falcon-Lang 2003a; Falcon-Lang et al. 2006). Many comprehensive studies exist on the terrestrial realm, but fewer have focussed on the aquatic setting, and most detailed studies of paleoenvironment have been primarily within the Joggins Formation. Details of the three paleoenvironment types follow.

\section{Terrestrial Drylands}

The red beds of the Joggins Formation and the older Little River Formation are evidence that wetlands were not the sole 


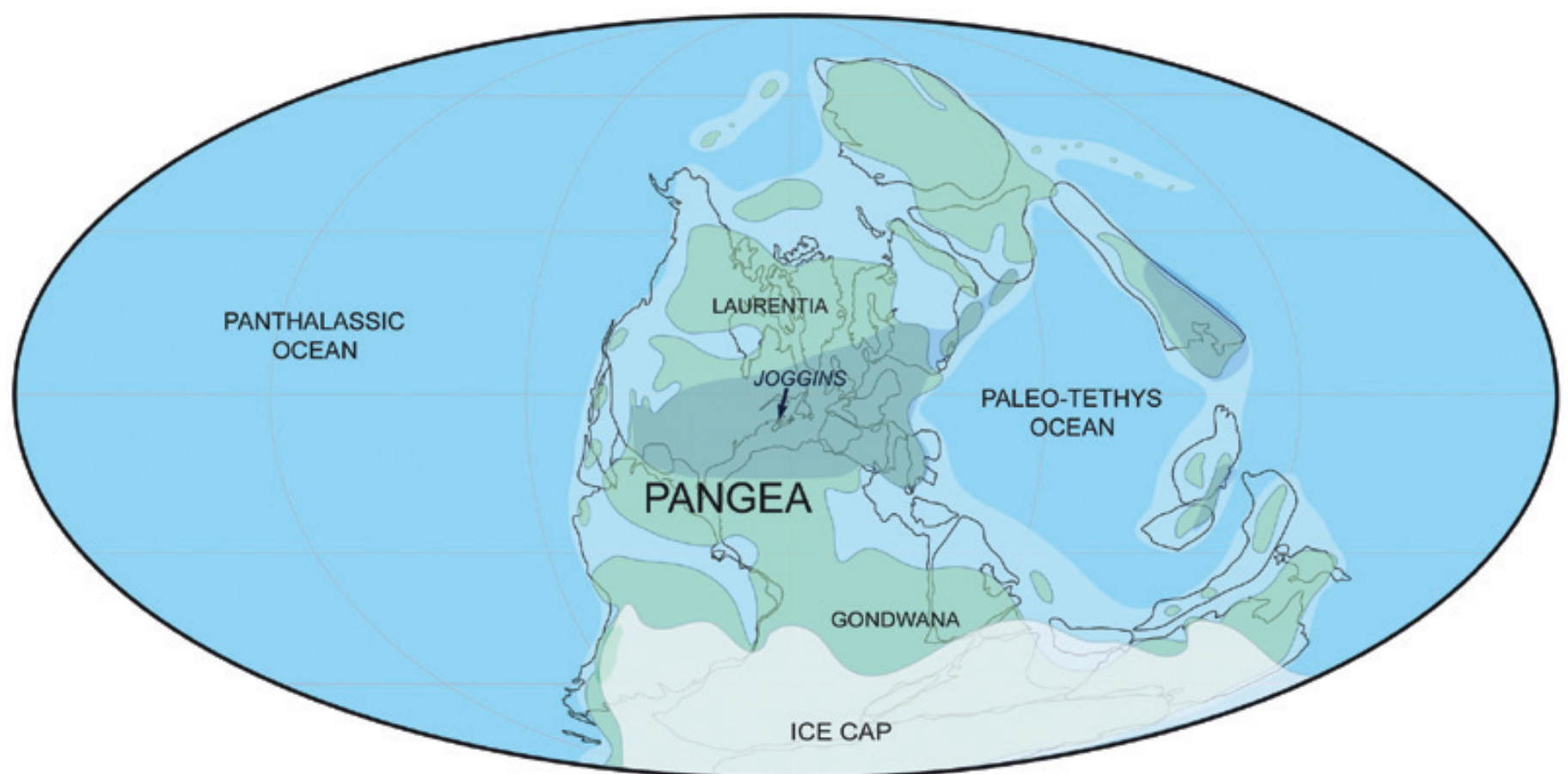

Deep Ocean

Continental Shelves

Land Mass

Tropical Peat Forest Biome

Polar Ice Sheets

Fig. 6. The approximate location of Joggins within the "tropical peat forest biome" on the supercontinent of Pangea during the late Carboniferous Period (from Boon and Calder 2007).

environment-type exhibited within the World Heritage Site. Terrestrial drylands are associated with well-drained alluvial plain facies described by Davies et al. (2005) and were dominated by dryland plant communities composed primarily of pteridosperms (seed ferns) and large cordaitalean trees (Falcon-Lang and Scott 2000; Falcon-Lang 2003b; Falcon-Lang 2007). The trees belong to an extinct order of gymnosperms, the Cordaitales, related most closely to conifers; however, chemosystematic and microstructural investigations of cordaites, other conifers, and seed ferns revealed that cordaites were no more closely related to conifers than they were to seed ferns (Mosle et al. 2002).

Cordaitaleans reached heights of approximately $45 \mathrm{~m}$; grew under humid tropical conditions; lived in an environment where wildfire occurred; and probably lived primarily in an upland setting (Falcon-Lang and Scott 2000; Falcon-Lang and Bashforth 2004), an important finding as this indicates that upland floras may have existed earlier than previously thought (Falcon-Lang and Scott 2000). Cordaitalean trees of the Boss Point Formation have also been noted as potentially the earliest evidence of log jams in the fossil record (Gibling et al. 2010), but the jams have only been noted (Calder 1998; Falcon-Lang and Scott 2000; Gibling et al. 2010) and have yet to be documented in detail.

Very rare cuticles of indeterminate scorpions and eurypterids have been found in the dryland facies of the Joggins section (Stankiewicz et al. 1998; Falcon-Lang et al. 2006). Interestingly, these cuticles were used by Stankiewicz et al. (1998) to help determine the contribution of animal remains to the formation of kerogen, which may be higher than previously thought.

In a quantitative analysis of fossils from the Joggins Formation using species diversity indices, Falcon-Lang (2003c) showed that growing conditions in the terrestrial drylands were stressed and that community composition differs considerably from wetland communities within the same formation. That author noted that sequence stratigraphy of the Joggins Formation suggests that the dryland flora grew in continental-interior environments (lowstand aridity) as opposed to wetland flora that grew in humid coastal settings (highstand humidity). A fossil assemblage from a 2-m-thick sandstone bed within the Joggins Formation displays a unique dryland assemblage of land snails (Dendropupa), archanodontid bivalves, and tetra- 
pods such as Baphetes, a fauna probably representing a dryland "waterhole" setting, the first of its kind to be described in the Carboniferous (Hebert and Calder 2004; Falcon-Lang et al.2004). Falcon-Lang et al. (2004) considered the seasonal drainages and waterholes of present-day central and northern Australia to be modern analogues of this paleoenvironment.

\section{Terrestrial Wetlands}

The wetland settings within the Joggins section, in which the standing lycopsid trees (specifically, Sigillaria and Lepidodendron) are primarily preserved, are interpreted as representing a disturbance-prone system with heavy rainfall and seasonal flooding (Falcon-Lang 1999, Calder et al. 2006). Wetlands are associated with the poorly drained coastal plain unit of Davies et al.(2005), where communities were composed of amphibians, reptiles, arthropods, pteridosperms, ferns, lycopsids, cordaitaleans, and calamiteans (Falcon-Lang et al. 2006). Secondary succession is apparent within the wetland environment: as lycopsids periodically drowned by flooding events, Calamites (a disturbance-tolerant relative of the modern day horsetail Equisetum) would regenerate and flourish(Calder et al.2006).

Cordaitalean trees are a primary feature of dryland and upland communities, but they were also found in wetlands (Falcon-Lang 2005a). It was therefore once thought that cordaitalean trees may have represented early mangrove-type communities (Raymond and Phillips 1983). Falcon-Lang (2005a) assessed this hypothesis and found that, while the trees could grow in close proximity to brackish seas and sedimentological evidence suggests that at times they were partially submerged, no evidence to date suggests that they were mangroves in the strict sense.

\section{Coastal Plains and Seas}

The aquatic environment and its degree of marine influence has been the subject of continued debate for decades. Until recently, the aquatic fauna of the Joggins Formation could not provide further information regarding the paleoenvironment because no diagnostic marine (salinity $\approx 35 \mathrm{ppt}$ ) or freshwater (salinity $<0.5 \mathrm{ppt}$ ) organisms had been identified. The majority of the fauna includes: bivalves with a freshwater affinity (Naiadites, Curvirimula, Archanodon); poorly preserved agglutinated estuarine $(\approx$ marginal marine; salinity $\approx 0.5-30$ ppt) foraminifera; ostracods (Velatomorpha) with an estuarine affinity; scales and bone material (teeth, ribs, etc.) of bony (rayfinned and lobe finned) and cartilaginous fish; microconchid worm tubes (long misidentified as Spirorbis polychaete worms: Taylor and Vinn, 2006); shrimp (Pygocephalus); and horseshoe crab trackways (Kouphichnium).

Previous studies of the calcareous shales in the Joggins Formation suggested a marginal marine ( $\approx$ estuarine $)$ setting based on: faunal composition (see above); association of carbonaceous strata with rooted mudstones and coals; and alluvialchannel deposits (e.g., Duff and Walton 1973; Gibling and Kalkreuth 1991). A marginal marine setting also is supported by two later studies that focused on faunal and sedimentological analyses of different beds within the Joggins Formation. Trace fossils (including Kouphichnium and annelid traces belonging to the genera Cochlichnus and Treptichnus) and agglutinated foraminifera, recovered from sandstone and mudrock beds in the middle of the Joggins Formation, suggest the presence of marine-influenced waters in an estuarine-type setting (Archer et al. 1995). Sedimentological structures such as ladder-back and double-crested ripples found in the beds are also indicative of, but not limited to, a tidally influenced setting (Archer $e t$ al. 1995). A second study supporting this conclusion was based on faunal associations and morphological features of the ostracods found within limestone beds of the Joggins Formation (Tibert and Dewey 2006).

The only geochemical analysis of fossil material from the Joggins section was on Naiadites bivalves from the upper part of the section(Brand 1994). The strontium, magnesium, sodium, manganese and iron contents significantly differed from those of coeval tropical marine molluscs, suggesting that the Joggins material is from a near-shore lacustrine (non-marine) setting with slightly dysaerobic waters (Brand 1994). This finding is in direct contrast to the previous work mentioned and thus the degree of marine influence at the site remained a matter for debate until recently. Grey et al. (2011) studied the limestones throughout the entire Joggins Formation and found evidence to suggest a waning marine influence. At the bottom of the Formation, echinoderms, brachiopod fragments, and pyritized ostracods were found in thin section, indicative of marine conditions; closer to the top of the Formation there were no echinoderms and many more non-marine bivalves (Naiadites and Curvirimula) were present (Grey et al. 2011).

\section{The "Tree Hollow Fauna"}

Common features of the Late Carboniferous tropical landscape evidenced by the Joggins succession included wildfire (perhaps promoted by high atmospheric-oxygen content) and seasonal and/or storm flooding events. Both features play a role in possible explanations for the famous "tree hollow fauna" of Joggins. Studies of fusain (fossil charcoal) in the Joggins section indicate that wildfires were frequent (Falcon-Lang 1999, 2000; Hower et al. 2000). There were two types of fire-prone plant communities: cordaite/conifer forests occurring in dry, upland niches; and a wetland community dominated by medullosan pteridosperms (seed ferns) and tree-sized club mosses (lycopsids), such as Sigillaria and Lepidodendron (Falcon-Lang 1999). Flooding is evidenced to some extent by upright sediment-filled trees whose trunks contain some of the most famous discoveries at Joggins, including Hylonomus lyelli.

Animals such as Hylonomus and at least eleven other tetrapod taxa, as well as detritovorous invertebrates and insects, may have been killed by wildfires (Falcon-Lang 1999) or flooding events that entombed the fauna in the trees, where at least some of the tetrapods may have been living/denning (Calder et al. 2005b). Fragments of plant material are also frequently found within sediment-filled trees that may have been drowned 
by large-scale, perhaps seasonal, flooding events (Calder et al. 2006). Lycopsids, the dominant tree of the wetland community, would rot from the inside and create a hollow trunk that may have been used as a living space for some animals (Calder et al. 2005b). Further flooding events would fill the hollowed tree with sediment and plant material, entombing the animals where they denned (Calder et al. 2005b).

Denning is one of three primary scenarios used to explain the occurrence of the tree hollow fauna. Two other scenarios have been proposed. In one, the animals (and plants) are postulated to have been washed into the trunk after death by flooding. In the other, the animals are envisaged as having fallen into partially buried hollowed trunks; this is known as the "pitfall theory" (Calder et al. 2005b). Early views, especially of Lyell, favoured the pitfall explanation, whereas a more recent study has favoured the denning scenario (Calder et al. 2005b); but the taphonomic and sedimentological details of the latter have yet to be published.

\section{Future Research}

In terms of improving the understanding of the paleoenvironmental context of the Joggins section(i.e., the entire World Heritage site), we see three areas as most promising. First, a need clearly exists to expand the research outside of the Joggins Formation; for instance, the log jams at Boss Point certainly warrant further study. Second, geochemical, specifically isotopic and trace-element studies, may be particularly useful in tracking potential changes in paleoclimate throughout the time represented by the World Heritage Site section. Such work would also provide an opportunity to explore the correlation of climatic and paleoenvironmental conditions with evolutionary patterns and biodiversity. Geochemical studies, however, must proceed with caution as diagenetic alterations can severely affect results. As Falcon-Lang (2003a) indicated, considerably more research is required to understand the impact of medium-term global environmental change on biodiversity, a subject of particular relevance today as the world is in the midst of a biodiversity crisis (e.g., Lawton and May 1995; Pimm et al. 1995; Thomas et al. 2004; Barnosky et al. 2011). Finally, publication of sedimentological and paleontological evidence would be useful in moving forward with hypotheses on the intriguing and well-preserved tree hollow fauna.

The Carboniferous Period, which has supplied the world with its main source of energy over the past few centuries, witnessed the highest atmospheric oxygen concentration in Earth history; and was a key time in evolution as vertebrates in the form of reptiles became independent of the aquatic environment. Few, if any, broadly based comparative analyses or synthesis of Carboniferous sites around the world exist. A couple of publications deal with specific aspects. One of these, by Carroll (1994), dealt with the tetrapods and noted that the East Kirkton (Scotland) tetrapod faunas were most similar to those of Joggins. The other, by DiMichele and Falcon-Lang (2011), reviewed aspects of Carboniferous to earliest Permian fossil forests preserved in growth position. In situ forests preserved in a stratigraphic series as at Joggins can, with limitations, provide unique knowledge of forest ecology and spatial patterns within specific habitats.

Perhaps the best example of a synthesis of global Carboniferous sites is an unpublished analysis written as part of the Joggins Fossil Cliffs nomination package to UNESCO for World Heritage status (Falcon-Lang 2002). This analysis compared other globally significant Pennsylvanian sites to Joggins. While extremely useful, the report focused on the prerequisites and benchmarks derived from the Questions and Recommendations of the International Union for Conservation of Nature (IUCN) for evaluation of fossil sites. Overall, nine sites were considered under three primary categories: the fossil record of biodiversity; the nature, quality and variability of the fossil archive; and the permanence (integrity) and scientific impact of the site. It may now be useful to expand that review from these three categories to include a synthesis on what we know about the Late Carboniferous world in general - from climate to paleogeography to faunal changes - based on critical sites globally.

\section{CONCLUSION}

Much of the recent research related to the Joggins Fossil Cliffs falls into three main categories: general geology (stratigraphy and sedimentology); paleobiology (taxonomic description/ discovery); and paleoecology. This research helped to form the foundation and breadth of knowledge that allowed Joggins to be recognized as a UNESCO World Heritage Site. Within this framework we have highlighted some gaps and opportunities that include, but are certainly not limited to, studies on: the uppermost formations (Springhill Mines and Ragged Reef) within the World Heritage Site; paleosols; floral and trace fossil taxonomy; and microevolutionary patterns exhibited within the Site, with potential to couple this with geochemical work. We also recognize that many more areas of potential research exist.

Falcon-Lang et al. (2006) highlight that publication records have dramatically increased over time since the 1850 s and projected that trend to continue throughout the past decade. We can now confirm that their predictions were indeed correct and were in fact exceeded, with over 40 publications on the Joggins site and/or material in the past decade (2000-2010). With the chance of discovery remaining high and the opportunity to use the site as a benchmark of the Carboniferous world, the Joggins locality will remain an area of interest to researchers for a long time to come.

\section{ACKNOWLEDGMENTS}

This work was funded by a National Sciences and Engineering Research Council PDF to Melissa Grey and a National Sciences and Engineering Research Council Discovery Grant to Zoe V. Finkel. Jenna Boon (JFI) and two anonymous reviewers provided constructive feedback. We especially thank Co-Editor 
Rob Fensome and Associate Editor Martin Gibling for their insightful comments and suggestions which have significantly improved this paper.

\section{REFERENCES}

Allen, J.P., Fielding, C.R., Gibling, M.R., and Rygel, M.C. 2011. Fluvial response to paleo-equatorial climate fluctuations during the late Paleozoic ice age. Geological Society of America Bulletin, 123, pp. 1524-1538.

Archer, A.W., Calder, J.H., Gibling, M.R., Naylor, R.D., Reid, D.R., and Wightman, W.G. 1995. Invertebrate trace fossils and agglutinated foraminifera as indicators of marine influence within the classic Carboniferous section at Joggins, Nova Scotia, Canada. Canadian Journal of Earth Sciences, 32, pp. 2027-2039.

Baird, D. 1982. A small temnospondyli amphibian from the Lower Pennsylvanian of Nova Scotia. Journal of Vertebrate Paleontology, 56, pp. 1302-1305.

Barnosky, A.D., Matzke, N., Susumu, T.,Wogan, G.O. U., Swartz, B., Quental, T.B, Marshall, C., McGuire, J.L., Lindsey, E.L., Maguire, K.C., Mersey, B., and Ferrer, E. A. 2011. Has the Earth's sixth mass extinction already arrived? Nature, 417, pp. 51-57.

Bell, W.A. 1912. Joggins Carboniferous section of Nova Scotia. Geological Survey of Canada, Summary Report for 1911, pp. 328-333.

Bell, W.A. 1914. Joggins Carboniferous section, Nova Scotia. Geological Survey of Canada, Department of Mines, Summary Report for 1912, pp. 360-371.

Bell, W.A. 1944. Carboniferous rocks and fossil floras of northern Nova Scotia. Geological Survey of Canada, Memoir 238, $119 \mathrm{p}$.

Benton, M.J., and Donoghue, P.C.J. 2007. Paleontological evidence to date the Tree of Life. Molecular Biology and Evolution, 24, pp. 26-53.

Boon, J., and Calder, J.H. 2007. Nomination of the Joggins Fossil Cliffs for inscription on the World Heritage List, United Nations Educational, Scientific and Cultural Organization, 129 p. URL < http://www.whc.unesco.org/en/list/1285/documents $>$ and $<$ http://jogginsfossilcliffs.net/research/Collection.php> January, 2011.

Brand, U. 1994. Continental hydrology and climatology of the Carboniferous Joggins Formation (lower Cumberland Group) at Joggins, Nova Scotia evidence from the geochemistry of bivalves. Palaeogeography, Palaeoclimatology, Palaeoecology, 106, pp. 307-321.

Browne, G.H., and Plint, A.G. 1994. Alternating braidplain and lacustrine deposition in a strike-slip setting the Pennsylvanian Boss Point Formation of the Cumberland Basin, Maritime Canada. Journal of Sedimentary Research Section B Stratigraphy and Global Studies, 64, pp. 40-59.

Calder, J.H. 1994. The impact of climate change, tectonics and hydrology on the formation of Carboniferous tropical intermontane mires; the Springhill Coalfield, Cumberland
Basin, Nova Scotia. Palaeogeography, Palaeoclimatology, Palaeoecology, 106, pp. 323-351.

Calder, J.H. 1998. The Carboniferous evolution of Nova Scotia. In Lyell: the past is the key to the present. Edited by $\mathrm{D}$. Blundell and A.C. Scott. Geological Society of London, Special Publication, 143, pp. 296-331.

Calder, J.H. 2006. "Coal Age Galapagos": Joggins and the lions of Nineteenth Century geology. Atlantic Geology, 42, pp. 37-51.

Calder, J.H., Rygel, M.C., Ryan, R.J., Gibling, M.R., FalconLang, H.J., and Hebert, B.L. 2005a. Stratigraphy and sedimentology of early Pennsylvanian red beds at Lower Cove, Nova Scotia, Canada: the Little River Formation with redefinition of the Joggins Formation. Atlantic Geology, 41, pp. 143-167.

Calder, J.H., Scott, A.C., and Milner, A.C. 2005b. The tree hollow fauna of Joggins: Ockham's Razor fells the Pitfall Theory. In North American Paleontology Convention, Halifax, Programme and Abstracts. Paleobios, Museum of Paleontology, University of California, Berkeley, 25, p.28.

Calder,J.H., Gibling, M.R., Scott, A.C., Davies, S.J., and Hebert, B.L. 2006. A fossil lycopsid forest succession in the classic Joggins section of Nova Scotia: paleoecology of a disturbance-prone Pennsylvanian wetland. In Wetlands through time. Edited by S. Greb and W.A. DiMichele. Geological Society of America Special Paper 399, pp. 169-195.

Carroll, R.L. 1963. A microsaur from the Pennsylvanian of Joggins, Nova Scotia. Natural History Papers, National Museum of Canada, Department of Northern Affairs and National Resources Ottawa, no.22, 13 p.

Carroll, R.L. 1964. The earliest reptiles. Journal of the Linnean Society of London (Zoology),45, pp. 61-83.

Carroll, R.L. 1966. Microsaurs from the Westphalian B of Joggins, Nova Scotia. Proceedings of the Linnean Society of London, 177, pp. 63-97.

Carroll, R.L. 1967. Labyrinthodonts from the Joggins Formation. Journal of Paleontology, 41, pp. 111-142.

Carroll, R.L. 1969. Problems of origin of reptiles. Biological Reviews of the Cambridge Philosophical Society, 44, pp. 393-432.

Carroll, R.L. 1970a. The ancestry of reptiles. Philosophical Transactions of the Royal Society of London, 257, pp. 267 308.

Carroll, R.L. 1970b. The earliest known reptiles. Yale Scientific Magazine, pp. 16-23.

Carroll, R.L. 1982. Early evolution of reptiles. Annual Review of Ecology and Systematics, 13, pp. 87-109.

Carroll, R.L. 1992. The primary radiation of terrestrial vertebrates. Annual Review of Earth and Planetary Sciences, 20, pp. 45-84.

Carroll, R.L. 1994. Evaluation of geological age and environmental-factors in changing aspects of the terrestrial vertebrate fauna during the Carboniferous. Transactions of the Royal Society of Edinburgh Earth Sciences, 84, pp. 427-431. 
Carroll, R.L. 2001. The origin and early radiation of terrestrial vertebrates. Journal of Paleontology, 75, pp. 1201-1213.

Chapelle, G., and Peck, L.S. 1999. Polar gigantism dictated by oxygen availability. Nature, 399, pp. 114-115.

Copeland, M.J. 1959. Coalfields, west half Cumberland County, Nova Scotia. Geological Survey of Canada Memoir 298, $89 \mathrm{p}$.

Dafoe, L., Stimson, M., and Gibling, M.R. 2011. One more piece to the puzzle: new developments in the trace fossil record from the Pennsylvanian Joggins Formation. Atlantic Geoscience Society Colloquium Program with Abstracts, 37, p. 18.

Davies, S.J., and Gibling, M.R. 2003. Architecture of coastal and alluvial deposits in an extensional basin: the Carboniferous Joggins Formation of eastern Canada. Sedimentology, 50, pp. 415-439.

Davies, S.J., Gibling, M.R., Rygel, M.C., Calder, J.H., and Skilliter, D.M. 2005. The Pennsylvanian Joggins Formation of Nova Scotia: sedimentological log and stratigraphic framework of the historic fossil cliffs. Atlantic Geology, 41, pp. 115-142.

Davydov, V.I., Wardlaw, B.R., and Gradstein, F.M. 2004. The Carboniferous Period. In A geologic time scale. Edited by F.M.Gradstein, J.G. Ogg, and A.G. Smith. 2004. Cambridge University Press, Cambridge, pp. 222-248.

Davydov, V. I., Crowley, J.L. Schmitz, M.D., and Poletaev V. I. 2010. High-precision U-Pb zircon age calibration of the global Carboniferous time scale and Milankovitch band cyclicity in the Donets Basin, eastern Ukraine. Geochemistry, Geophysics, Geosystems, 11, pp. 1-22.

Dawson, J.W. 1868. Acadian geology: the geological structure, organic remains, and mineral resources of Nova Scotia, New Brunswick, and Prince Edward Island. Second edition. MacMillan and Co., London, 694 p.

Dawson, J.W. 1890. On burrows and tracks of invertebrate animals in Paleozoic rocks, and other markings. Quarterly Journal of the Geological Society of London, 46, pp. 595-618.

Deal, A.J. 1991. The stratigraphy and depositional environments of the Ragged Reef Formation in the Athol Syncline, Cumberland Basin, Nova Scotia, Canada. Unpublished M.Sc. thesis, Acadia University, Wolfville, Nova Scotia, Canada, $255 \mathrm{p}$.

DiMichele, W.A., and Falcon-Lang, H.J. 2011. Fossil forests in growth position ( $\mathrm{T} 0$ assemblages): origin, taphonomic biases and palaeoecological significance. Journal of the Geological Society, 168, pp. 585-605.

DiMichele, W.A., Montañez, I.P., Poulsen, C.J., and Tabor, N.J. 2009. Climate and vegetational regime shifts in the late $\mathrm{Pa}$ leozoic ice age earth. Geobiology, 7, pp. 200-226.

DiMichele, W.A., Cecil, B., Montanez, I., and Falcon-Lang, H.J. 2010. Cyclic changes in Pennsylvanian paleoclimate and effects on floristic dynamics in tropical Pangaea. International Journal of Coal Geology, 83, pp. 329-344.

DiVenere, V.J., and Opdyke, N.D. 1991. Magnetic polarity stratigraphy and Carboniferous paleopole positions from the Joggins section, Cumberland structural basin, Nova Scotia.
Journal of Geophysical Research - Solid Earth and Planets, 96, pp. 4051-4064.

Dolby, G. 1991. The palynology of the western Cumberland Basin, Nova Scotia. Nova Scotia Department of Mines and Energy Open File Report 91-006, 39 p.

Dolby, G. 2003. Palynological analysis of ten outcrop and corehole samples from Nova Scotia. Nova Scotia Department of Natural Resources, Open File Report 2003-005, 7 p.

Duff, P.M.D., and Walton, E.K. 1973. Carboniferous sediments at Joggins, Nova Scotia. Septième Congrès International de Stratigraphie et de Géologie du Carbonifère, Krefeld, Compte Rendu, 2, pp. 365-379.

Falcon-Lang, H.J. 1999. Fire ecology of a late Carboniferous floodplain, Joggins, Nova Scotia. Journal of the Geological Society, 156, pp. 137-148.

Falcon-Lang, H.J. 2000. Fire ecology of the Carboniferous tropical zone. Palaeogeography, Palaeoclimatology, Palaeoecology, 164, pp. 355-371.

Falcon-Lang, H.J. 2002. Comparative analysis of Pennsylvanian fossil sites. Unpublished report for UNESCO, 119 p.

Falcon-Lang, H.J. 2003a. Response of late Carboniferous tropical vegetation to transgressive-regressive rhythms at Joggins, Nova Scotia. Journal of the Geological Society, 160, pp. 643-648.

Falcon-Lang, H.J. 2003b. Anatomically-preserved cordaitalean trees from Lower Pennsylvanian (Langsettian) dryland alluvial-plain deposits at Joggins, Nova Scotia. Atlantic Geology, 39, pp. 255-261.

Falcon-Lang, H.J. 2003c. Late Carboniferous tropical dryland vegetation in an alluvial-plain setting, Joggins, Nova Scotia, Canada. Palaios, 18, pp. 197-211.

Falcon-Lang, H.J. 2005a. Small cordaitalean trees in a marineinfluenced coastal habitat in the Pennsylvanian Joggins Formation, Nova Scotia. Journal of the Geological Society, 162, pp. 485-500.

Falcon-Lang, H.J. 2005b. Adpressed tree-fern trunks from the Early Pennsylvanian Joggins Formation of Nova Scotia. Atlantic Geology, 41, pp. 169-172.

Falcon-Lang, H.J. 2006. A history of research at the Joggins fossil cliffs of Nova Scotia, Canada, the world's finest Pennsylvanian section. Proceedings of the Geologists Association, 117, pp. 377-392.

Falcon-Lang, H.J. 2007. A Cordaixylon axis from well-drained alluvial plain facies in the Lower Pennsylvanian Joggins Formation of Nova Scotia. Atlantic Geology, 43, pp. 87-90.

Falcon-Lang, H.J. 2009. Earliest history of coal mining and grindstone quarrying at Joggins, Nova Scotia, and its implications for the meaning of the place name "Joggins". Atlantic Geology, 45, pp. 1-20. http://dx.doi.org/ doi:10.4138/ atlgeol.2009.001

Falcon-Lang, H.J., and Bashforth, A.R. 2004. Pennsylvanian uplands were forested by giant cordaitalean trees. Geology, 32 , pp. 417-420.

Falcon-Lang, H.J., and Calder, J.H. 2005. Sir William Dawson (1820-1899): a very modern palaeobotanist. Atlantic Geology, 41, pp. 103-114. 
Falcon-Lang, H.J., and Scott, A.C. 2000. Upland ecology of some Late Carboniferous cordaitalean trees from Nova Scotia and England. Palaeogeography, Palaeoclimatology, Palaeoecology, 156, pp. 225-242.

Falcon-Lang, H.J., Rygel, M.C., Calder, J.H., and Gibling, M.R. 2004. An early Pennsylvanian waterhole deposit and its fossil biota in a dryland alluvial plain setting, Joggins, Nova Scotia. Journal of the Geological Society, 161, pp. 209-222.

Falcon-Lang, H.J., Benton, M.J., Braddy, S.J., and Davies, S.J. 2006. The Pennsylvanian tropical biome reconstructed from the Joggins Formation of Nova Scotia, Canada. Journal of the Geological Society, 163, pp. 561-576.

Ferguson, L. 1966. The recovery of some large track-bearing slabs from Joggins, Nova Scotia. Maritime Sediments, 2, pp. 128-130.

Ferguson, L. 1975. The Joggins section. Maritime Sediments, 11, p. 69.

Gardiner, J., and Gibling, M.R. 2005. Pedogenic mud aggregates in the Boss Point Formation, Joggins, Nova Scotia. Atlantic Geoscience Society Colloquium Program with Abstracts, 31, p. 62.

Gibling, M.R. 1995. Upper Paleozoic rocks, Nova Scotia. In Geology of the Appalachian-Caledonian Orogen in Canada and Greenland. The geology of North America, Volume F-1. Edited by H. Williams. Geological Society of America, pp. 493-523.

Gibling, M.R., and Kalkreuth, W.D. 1991. Petrology of selected carbonaceous limestones and shales in late Carboniferous coal basins of Atlantic Canada. International Journal of Coal Geology, 17, pp. 239-272.

Gibling, M.R., and Rygel, M.C. 2008. Late Paleozoic cyclic strata of Euramerica: recognition of Gondwanan glacial signatures during periods of thermal subsidence. In Resolving the Late Paleozoic Ice Age in time and space. Edited by C.R. Fielding, T.D. Frank, and J.L. Isbell. Geological Society of America Special Publication, 441, pp. 219-233.

Gibling, M.R., Zentilli, M., and McCready, R.G.L. 1989. Sulphur in Pennsylvania coals of Atlantic Canada: geologic and isotopic evidence for a bedrock evaporite source. International Journal of Coal Geology, 11, pp. 81-104.

Gibling, M.R., Calder, J.H., Ryan, R., van de Poll, H. W., and Yeo, G.M. 1992. Late Carboniferous and Early Permian drainage patterns in Atlantic Canada. Canadian Journal of Earth Sciences, 29, pp. 338-352.

Gibling, M.R., Culshaw, N., Rygel, M.C., and Pascucci, V. 2008. The Maritimes Basin of Atlantic Canada: basin creation and destruction in the collisional zone of Pangea. In The sedimentary basins of the United States and Canada. Edited by A.D. Miall. Amsterdam, Elsevier, pp. 211-244.

Gibling, M.R., Bashforth, A.R., Falcon-Lang, H.J., Allen, J.P., and Fielding, C.R. 2010. Log jams and flood sediment buildup caused channel abandonment and avulsion in the Pennsylvanian of Atlantic Canada. Journal of Sedimentary Research, 80, pp. 268-287.

Godfrey, S., Fiorillo, A.R., and Carroll, R.L. 1987. A newly discovered skull of the temnospondyli amphibian Dendrerpe- ton acadianum Owen. Canadian Journal of Earth Sciences, 24, pp. 796-805.

Godfrey, S., Holmes, R.B., and Laurin, M. 1991. Articulated remains of a Pennsylvanian embolomere (Amphibia: Anthracosauria) from Joggins, Nova Scotia. Journal of Vertebrate Paleontology, 11, pp. 213-219.

Graham, J.B., Dudley, R., Aguilar, N., and Gans, C. 1995. Implications of the late Palaeozoic oxygen pulse for physiology and evolution. Nature, 375, pp. 117-120.

Grey, M., Pufahl, P.K., and Abdul, A.A. 2011. Using multiple environmental proxies to determine degree of marine influence and paleogeographical position of the Joggins Fossil Cliffs UNESCO World Heritage Site. Palaios, 26, pp. 256-263.

Hamblin, A.P. 2001. Stratigraphy, sedimentology, tectonics, and resource potential of the Lower Carboniferous Mabou Group, Nova Scotia. Geological Survey of Canada Bulletin, $568,164 \mathrm{p}$.

Hebert, B.L., and Calder, J.H. 2004. On the discovery of a unique terrestrial faunal assemblage in the classic Pennsylvanian section at Joggins, Nova Scotia. Canadian Journal of Earth Sciences, 41, pp. 247-254.

Holmes, R.B., and Carroll, R.L. 2010. An articulated embolomere skeleton (Amphibia: Anthracosauria) from the Lower Pennsylvanian (Bashkirian) of Nova Scotia. Canadian Journal of Earth Sciences, 47, pp. 209-219.

Holmes, R.B., Carroll, R.L., and Reisz, R.R. 1998. The first articulated skeleton of Dendrerpeton acadianum (Temnospondyli, Dendrerpetontidae) from the Lower Pennsylvanian locality of Joggins, Nova Scotia, and a review of its relationships. Journal of Vertebrate Paleontology, 18, pp. 64-79.

Hower, J.C., Calder, J.H., Eble, C.F., Scott, A.C., Robertson, J.D., and Blanchard, L.J. 2000. Metalliferous coals of the Westphalian A Joggins Formation, Cumberland Basin, Nova Scotia, Canada: petrology, geochemistry, and palynology. International Journal of Coal Geology, 42, pp. 185-206.

Kaplan, S.S., Donahue, J., Carr, J.D., and Kelter, P.B. 1985. Analysis of the trace-element content of coals from the Carboniferous Cumberland Group, near Joggins, Nova Scotia, Canada. Canadian Journal of Earth Sciences, 22, pp. 626-629.

Lawton, J.H., and May, R.M.(Editors). 1995. Extinction rates. Oxford University Press, Oxford, U.K. 233 p.

Lucas, S.G., Hunt, A.P., Calder, J.H., Reid, D., Hebert, B., and Stimson, M . 2005. Tetrapod footprints from Joggins, Nova Scotia: a template for understanding Carboniferous tetrapod footprints. Geological Association of Canada Mineralogical Association of Canada, Program with Abstracts, 30, pp. 116-117.

Matthew, G.F. 1903. On batrachian and other footprints from the Coal Measures of Joggins, N.S. Natural History Society of New Brunswick Bulletin, 21, pp. 103-108.

Matthew, G.F. 1905. New species and a new genus of batrachian footprints of the Carboniferous system in eastern Canada. Royal Society of Canada, Proceedings and Transactions, 10, pp. 77-121. 
McLeod, J. 2010. Viséan tectonostratigraphy of the Cumberland Basin of New Brunswick and Nova Scotia. Unpublished M.Sc. Thesis St. Mary's University, Halifax, Nova Scotia, Canada, $135 \mathrm{p}$.

Milner, A.C. 1987. The Westphalian tetrapod fauna; some aspects of its geography and ecology. Journal of the Geological Society of London, 144, pp. 495-506.

Milner, A.C. 1996. A revision of the temnospondyli amphibians from the Upper Carboniferous of Joggins, Nova Scotia. Special Papers in Palaeontology, 52, pp. 81-103.

Mosle, B., Collinson, M.E., Scott, A.C., and Finch, P. 2002. Chemosystematic and microstructural investigations on Carboniferous seed plant cuticles from four North American localities. Review of Palaeobotany and Palynology, 120, pp. 41-52.

Mossman, D.J., and Grantham, R.G. 1996. A recently discovered amphibian trackway (Dromillopus quadrifidus) at Joggins, Nova Scotia. Canadian Journal of Earth Sciences, 33, pp. 710-714.

Pimm, S.L., Russell, G.J. Gittleman, J.L., and Brooks T.M. 1995. The future of biodiversity. Science, 269, pp. 347-350.

Plint, A.G., and Browne, G.H. 1994. Tectonic event stratigraphy in a fluvio-lacustrine, strike-slip setting: the Boss Point Formation (Westphalian A), Cumberland Basin, Maritime Canada. Journal of Sedimentary Research, B64, pp. 341-364.

Quann, S.L., Young, A.B., Laroque, C.P., Falcon-Lang, H.J., and Gibling, M.R. 2010. Dendrochronological dating of coal mine workings at the Joggins Fossil Cliffs, Nova Scotia, Canada. Atlantic Geology, 46, pp. 185-194.

Raymond, A., and Phillips, T.L. 1983. Evidence for an Upper Carboniferous mangrove community. In Biology and ecology of mangroves. Tasks for vegetation science 8. Edited by H.J. Teas. W. Junk Publishers, Boston, MA, pp. 19-30.

Reed, B.C., Nance, R.D., Calder, J.H., and Murphy, J.B. 1993. The Athol Syncline: tectonic evolution of a Westphalian A-B depocentre in the Maritimes Basin, Nova Scotia. Atlantic Geology, 29, pp. 179-186.

Reisz, R.R. 1997. The origin and early evolutionary history of amniotes. Trends in Ecology and Evolution, 12, pp. 218222.

Reisz, R.R., and Modesto, S.P. 1996. Archerpeton anthracos from the Joggins Formation of Nova Scotia: a microsaur, not a reptile. Canadian Journal of Earth Sciences, 33, pp. 703-709.

Robinson, J., Ahlberg, P.E., and Koentges, G. 2005. The braincase and middle ear region of Dendrerpeton acadianum (Tetrapoda: Temnospondyli).Zoological Journal of the Linnean Society, 143 , pp. 577-597.

Rust, B.R., Gibling, M.R., and Legun, A.S. 1984. Coal deposition in an anastomosing-fluvial system: the Pennsylvanian Cumberland Group south of Joggins, Nova Scotia, Canada. In Sedimentology of coal and coal-bearing sequences. Edited by R.A.Rahmani and R.A. Flores. International Association of Sedimentologists Special Publication, 7, pp. 105-120.

Ryan, R.J., and Boehner, R.C. 1994. Geology of the Cumberland Basin, Cumberland, Colchester and Pictou counties,
Nova Scotia. Nova Scotia Department of Natural Resources, Mines and Energy Branch, Memoir 10, 222 p.

Ryan, R.J., Boehner, R.C., and Calder, J.H. 1991. Lithostratigraphic revisions of the upper Carboniferous to lower Permian strata in the Cumberland Basin, Nova Scotia and their regional implications for the Maritimes Basin in Atlantic Canada. Bulletin of Canadian Petroleum Geology, 39, pp. 289-314.

Rygel, M.C., and Gibling, M.R. 2006. Natural geomorphic variability recorded in a high-accommodation setting: fluvial architecture of the Pennsylvanian Joggins Formation of Atlantic Canada. Journal of Sedimentary Research, 76, pp. 1230-1251.

Rygel, M.C., and Shipley, B.C. 2005. "Such a section as never was put together before": Logan, Dawson, Lyell and midNineteenth Century measurements of the Pennsylvanian Joggins Section of Nova Scotia. Atlantic Geology, 41, pp. 87-102.

Rygel, M.C., Gibling, M.R., and Calder, J.H. 2004. Vegetationinduced sedimentary structures from fossil forests in the Pennsylvanian Joggins Formation, Nova Scotia. Sedimentology, 51, pp. 531-552.

Sahney, S., Benton, M.J., and Falcon-Lang, H.J. 2010. Rainforest collapse triggered Pennsylvanian tetrapod diversification in Euramerica. Geology, 38, pp. 1079-1082.

Salg, J., and Rygel, M.C. 2008. Sedimentology of the lower Springhill Mines Formation, Cumberland Basin, Nova Scotia. Geological Society of America Abstracts with Programs, 40, p. 82.

Sarjeant, W.A.S., and Mossman, D.J. 1978. Vertebrate footprints from Carboniferous sediments of Nova Scotia historical review and description of newly discovered forms. Palaeogeography Palaeoclimatology Palaeoecology, 23, pp. 279-306.

Scott, A.C. 1998. The legacy of Charles Lyell: advances in our knowledge of coal and coal-bearing strata. In Lyell: the past is the key to the present. Edited by D. Blundell, and A.C. Scott. Geological Society of London, Special Publication, 143, pp. 243-260.

Skilliter, D.M. 2001. Distal marine influence in the Forty Brine Section, Joggins, Nova Scotia, Canada. Unpublished M.Sc. Thesis, Boston College, Boston, Massachusetts, USA, 96 p.

Smith, M.G. 1991. The flood plain deposits and paleosol profiles of the late Carboniferous Cumberland coal basin, exposed at Joggins, Nova Scotia, Canada. Unpublished M.Sc. Thesis, University of Guelph, Guelph, Ontario, Canada, $372 \mathrm{p}$.

Spicer, J.I., and Gaston, K.J. 1999. Amphipod gigantism dictated by oxygen availability? Ecology Letters, 2, pp. 397403.

Stankiewicz, B.A., Scott, A.C., Collinson, M.E., Finch, P., Mosle, B., Briggs, D.E.G., and Evershed, R.P. 1998. Molecular taphonomy of arthropod and plant cuticles from the Carboniferous of North America: implications for the origin of kerogen. Journal of the Geological Society, 155, pp. $453-462$. 
Stevenson, J.S. 1967. Note on fossil teeth from Joggins Nova Scotia. Proceedings of the Geological Association of Canada, 18, pp. 109-114.

Stevenson, J.S., and Stevenson, L.S. 1966. Fluorine content of microsaur teeth from Carboniferous rocks of Joggins Nova Scotia. Science, 154, pp. 1548-1550.

Stimson, M., and MacRae, R.A. 2010. Evidence of fossil horseshoe crabs from Joggins, Nova Scotia: paleoichnology and paleoenvironmental implications. Atlantic Geoscience Society Colloquium Program with Abstracts, 36, p. 39.

Taylor, P.D., and Vinn, O. 2006. Convergent morphology in small spiral worm tubes ("Spirorbis") and its palaeoenvironmental implications. Journal of the Geological Society, London, 163, pp. 225-228.

Thomas, C.D., Cameron, A., Green, R.E., Bakkenes, M, Beaumont, L.J., Collingham, Y.C., Erasmus, B.F.N., Ferreira de Siqueira, M., Grainger, A., Hannah, L., Hughes, L., Huntley, B., van Jaarsveld, A.S., Midgley, G.F., Miles, L., OrtegaHuerta, M.A., Peterson, A.T., Phillips, O.L., and Williams, S.E. 2004. Extinction risk from climate change. Nature, 427, pp. 145-148.

Tibert, N.E., and Dewey, C.P. 2006. Velatomorpha, a new healdioidean ostracode genus from the early Pennsylvanian Joggins Formation, Nova Scotia, Canada. Micropaleontology, 52, pp. 51-66.
Utting, J., and Wagner, R.H. 2005. Megaflora of the Upper Carboniferous Cumberland Group, Joggins area, Nova Scotia and New Brunswick. Geological Association of Canada - Mineralogical Association of Canada Program with Abstracts, 30, p. 197.

Utting, J., Giles, P.S., Dolby, G., and Calder, J.H. 2005. New palynological data from Upper Visean, Namurian, and Westphalian rocks of the Joggins area, Nova Scotia and New Brunswick, Canada. Geological Association of Canada Mineralogical Association of Canada Program with Abstracts, 30, p. 197.

Utting, J., Giles, P.S., and Dolby, G. 2010. Palynostratigraphy of Mississippian and Pennsylvanian rocks, Joggins area, Nova Scotia and New Brunswick, Canada. Palynology, 34, pp. 43-89.

Waldron,J.W.F., and Rygel, M.C. 2005. Role of evaporite withdrawal in the preservation of a unique coal-bearing succession: Pennsylvanian Joggins Formation, Nova Scotia. Geology, 33, pp. 337-340.

Way, J.H., Jr. 1968. Bed thickness analysis of some Carboniferous fluvial sedimentary rocks near Joggins, Nova Scotia. Journal of Sedimentary Petrology, 38, pp. 424-433.

Editorial responsibility: Robert A. Fensome 